\title{
The Role of the International Administration in the Process of the State-Building in Kosovo
}

\author{
Valon Krasniqi \\ PhDc. South East European University \\ Ylber Aliu \\ PhDc. South East European University
}

Doi:10.5901/ajis.2015.v4n3s1p409

\begin{abstract}
The purpose of this research paper is to study the international administration in the process of the state-building in Kosovo. The paper will analyze the establishing, running and terminating the international administration in Kosovo. International administration has direct impact on state-building process. International governance in Kosovo is separated in two stages before and after declaration of independence. This research paper will try to explain the relationship between international administration and local institutions in the process of state-building - the case of Kosovo. Two methods are used in this paper for data collection. First, process tracing theory method. Second, data collection method, through structured questionnaire with respondents from different fields. Conclusion of the paper is that, Kosovo case has shown that the success or failure of an international administration mission depends on the clarity of the establishment, development and its conclusion.
\end{abstract}

Keywords: International Administration, State-Building, Election, Independence.

\section{Introduction}

The case of Kosovo has shown that the success or failure of international administration depends on the clarity of the establishment, development and termination.

To argue on this idea, this paper will first present the theoretical framework. Will continue with the context of the international administration in Kosovo, then we will present research results collected through a structured questionnaire, and in the end we will do the analysis of the results.

The methodology of the paper

The main hypothesis of this paper is that, the success of an international administration depends on the clarity of the establishment, development and termination.

This hypothesis consists of two variables. Independent variable is: clarity of establishment, development and termination. Meanwhile, the dependent variable is: the success of international administration. Consequently, the main factor affecting the success of an international administration depends on the clarity of the establishment, development and termination of the mission. The study focuses on the case of Kosovo. The data were collected through two methods. First, the method of process tracing theory. So, the collection of data through the chronological study through the analytical approach. Second, the method of collecting data through a structured questionnaire with respondents from various fields. However, we are focused mainly in specialized respondents in the field of law enforcement and security institutions.

\section{Theoretical Framework}

In the literature of international administration, there are various explanations for the relationship between the international administration and local institutions in the process of state - building.

Thus, the term "international administration includes a wide range of historical and contemporary experiences. In today presenting is not formal practice or institution in order that the custody of the United Nations or maintaining peace of the United Nations" (Caplan, R. 2005:16). Meanwhile, as part of international administration and direct and indirect aid of the state building means administration setting based on the authorization of the United Nations, in the service of 
peace, reconciliation and democratic institution building. (Tansey 2009:)".

On the other side, "The term state-building refers to broad international commitment (firstly, but not only through the United Nations) that extends beyond traditional mandates of peacekeeping and its construction, and is aimed at building or rebuilding of government institutions able to provide the physical and economic security for citizens. This includes activities related governance as electoral assistance, technical assistance for human rights and the rule of law, security sector reform, as well as some other ways of development aid" (Chesterman, 2005 :5).

Whereas, with a different meaning, "In simplest formulation, state-building, as understood by the international community since 1990, refers to a series of actions undertaken by national or international actors to reform and strengthen state institutions, which can be weakened or destroyed" (Caplan 2005a). From such a viewpoint, it will be investigated the case of Kosovo.

Also, in the literature there are various explanations why the international administration should be established in a territory. Thus, according to an explanation, "The collapse of governance structures (governance issues) or loss of citizenship elements (national issues), the separation of the territory from the State (East Timor), internal conflicts (Afghanistan, Cambodia, Somalia), disintegration of the state (Yugoslavia-Kosovo and Bosnia, Eastern Slavonia), noncolonialism (Namibia, western Iran) or belligerent occupation of territories (Irak). In these cases, third parties have intervened in some way to accomplish government vacuum, until the respective national institutions can be set from the local populations. (Rüdiger 2005: 649).

Missions of the United Nations in the Balkans, for example in Eastern Slovenia (UNTAES), international administrators have complete executive authority, but only for the purpose of transfer of territory from the control of one state in another state, while the mission involved in the organising of elections were not forced democratic regime development of self-government. In Bosnia, Kosovo and East Timor, new political systems were placed and in each case, international administrators were mandated to oversee the process through direct involvement. So the construction of democratic regimes was an important part of international missions. (Tansey 2009: 11).

Models as have acted international administrations are different. For instance, "In the case of Bosnia and Kosovo assessing previous experiences, it is suggested that the rule of law and the relevant state institutions must be installed before the population is called to participate in political decision making. Contrast access is the commitment of peoples and elites also in an early stage and keeping foreign involvement as less, an approach that has been made in the development of Afghanistan". (Rudiger 2005 :651).

\section{The Background of Establishing UNMIK ${ }^{1}$ Administration in Kosovo}

The context of the problem refers to the case of international administration of Kosovo as case study, as before proclaiming independence with UNMIK responsible for civil administration and KFOR responsible for the military administration, as well as after the declaration of independence with the EULEX mission responsible for the safety and security sector.

Until 1999, Kosovo has been in the administration and governance of the former - Yugoslav Federation. By the Constitution of 1974, Kosovo was part of the Federation, but there was no status of Republic. Consequently, in the early 90s, Kosovo did not enjoy the right to self- determination similarly to other former republics, according to the Badinter Commission (Pellet:1992). While, in the republics of former Yugoslavia (Slovenia, Croatia, Bosnia) had started the war, Kosovo continued to follow the course of peaceful setting of its status. This way of acting excluded from important processes because was not considered problematic, compared with republics where war started.

Despite the confrontation with the Serbian authorities, Kosovo Albanians developed parallel structures in education, taxes, as well as parallel political representation. The lack of progress by peaceful lines, and the fact that Kosovo is not addressed in the Dayton peace agreement, caused the radicalization of the young Albanians. In 1996, the Kosovo Liberation Army (KLA) made the first guerilla attacks. This elicited the harsh of Serb party (Simonsen:291-292, Caplan 2005a: 133-146, Lindsey, 2009:10-13 and Tansey 2009: 110-113).

After failing to reach the Rambouillet agreement and refusing to sign it by former Yugslavia side, NATO undertook 78 days air strike against fomer Yugoslavia military forces. After this, Former Yougoslavia was forced to give up and sign Kumanova Agreement with NATO. Security Council of United Nation approved Resolution 1244/1999 as basis of United Nation Mission in Kosovo. 
UNMIK Mission was installed after a dispute between the Serbian state and the movement resistance of Kosovo Albanians. It was mandated to oversee political and economic reconstruction of the territory. Since establishment, UNMIK played a key role in Kosovo's political transition and used the full available mechanisms to influence and directed democratic development. (Tansey 2009:109)

UNMIK, was established based on Resolution 1244 (1999) of the UN -SC, which provide complex structure consisting of a range of international institutions. The resolution had a number of objectives, including some immediately after the war, as : withdrawal of troops, demilitarization and the establishment of a more secure environment, as well as a number of explicit responsibilities to UNMIK. These were quite broad, ambitious and included: Promoting the establishment of Substantial Autonomy of self-government; Performing basic civil administration functions, wherever required; Organizing and overseeing the development of provisional democratic institutions of self-government; Holding elections; Facilitating the political process designed to determine Kosovo's future status; Overseeing the transfer of authority; Support and re-building of key infrastructure and other re-buildings; Support in coordination with international humanitarian organizations of the population; Maintaining order and the establishment and training of the local police forces, at the same time sending international police forces to serve in Kosovo; Promotion and protection of human rights; And securing and creating basic conditions for return and returns of displaced persons.(Tansey 2009: 113 and UNMIK mandate: http://www.un.org/en/peacekeeping/missions/unmik/mandate.shtml)

Whereas, in addition to the responsibilities and competences of UNMIK in Kosovo authorized security presence was NATO, through KFOR presence. The presence of UNMIK, was compiled by NATO forces, which have mandates of supervising the withdrawal of Serbian forces and ensuring a peaceful and stable environment for the local population and international presence in Kosovo. (Tansey 2009:110- 113). Military aspect of Resolution 1244/1999, based on the principles of G-8 foreign ministers authorized the sending of the military forces in Kosovo with main participation of the NATO. (Chesterman 2005:80). During the administration of UNMIK, we had strange division of power which UNMIK has exerted all real sovereignty, including the promotion and development of local self-government. While Serbia and Montenegro exerted formal sovereignty over the territory. (Tansey 2009:113)

Until holding the first local elections of then parliamentary initially, UNMIK was the only governing authority. 'Only governing mechanism, involving Kosovars was, the Kosovo Transitional Council (KTC). With the intention to include the main ethnic and political groups, designed to provide advices to the Special Representative of the Secretary-General of the United Nations (SRSG). On the other side was also created another higher body, called the Interim Administrative Council (IAC), consisting of Kosovo leaders as substitute of the parallel government created by Kosovo Albanians, who for several years provide basic public services and collect income. This council was empowered to make recommendations to the SRSG, who can accept but also refuse by giving a written response within seven days of the decision differently. (Chesterman 2005:132-133).

UNMIK consisted of a number of international organizations, but with an integrated structure with the leadership and coordination of the SRSG. To facilitate the implementation of the mandate, UNMIK composed of four pillars, each led by different organizations. The first was the Civil Administration led by (UNMIK), humanitarian aid (UNHCR), Institution Building (OSCE), and economic development (EU). SRSG was the main authority, while his four alternates appointed lead the one of the four pillars. Resolution 1244 included five stages of international management. The first had to do with the the establishment of the UNMIK administration. Strengthening the administration and its transfer to locals was the second phase, while preparations for the elections were made. Holding elections were the third phase. While the establishment of Kosovo institutions after the elections in the fourth phase. While the fifth phase after defining the status of Kosovo and the transfer of all responsibilities to locals. SRSG had powerful legislative and executive power. Also had power to appointment and dismissal in the civil administration and judiciary.(Caplan 2005b:37-39; Tansey 2009: 113-114; Knudsen and Lausten 2006:65-66).

The transfer of competencies to Kosovo institutions culminated in 2007 with the holding of parliamentary and local elections at the same time. The 2007 elections had led Vienna talks process for defining the status of Kosovo and expected the declaration of independence which was made on February 17, 2007. This was done in coordination with the main countries of the EU and the US, but not to Russia and China as the opposing of the independence. This is also reflected in the acceptance of the Ahtisaari who wanted to pass his proposal to the UN Security Council, but with the opposition of dissenting countries above mentioned with the Kosovo's independence, it did not happen.

After Proclamation of Independence of the Republic of Kosovo on 17 february 2008 (Kosovo Declaration of Independence 2008) by the Assamble of Kosovo and entry into force of Constitution(Kosovo Constitution 2008) in June 15,2008 , the role, responsibilities and powers of UNMIK were reduced in number as well as structure.

According to the report of the Secretary-General of the UN (S2208 / 692) to the UNMIK mission in Kosovo, as well 
as political situation, among others stated: With the entry into force of the Constitution of the Republic of Kosovo on June 15 2008, the Kosovo authorities have continued taking steps towards statehood. They have created the Ministry of Foreign Affairs, and opened diplomatic missions. While the new state continued to be known by many states. The establishment of the Ministry of Security Force (MKSF). Also in the process of establishing a state, Kosovo continued to apply for membership in the International Monetary Fund (IMF), World Bank (WB). Kosovo's parliament continue to legislate without reference of the power of the SRSG, based on resolution 1244 (1999) or the Constitutional Framework. (Reports of the Secretary General of the UN: 2008 and 2009). In the declaration of Kosovo independence adopted by Parliament of Republic of Kosovo on 17 February 2008, apart from other things, states that: "We invite and welcome an international civilian presence to supervise our implementation of the Ahtisaari plan and a rule of law mission led by the European Union" (Declaration of Kosovo independence). Also, the statement said: "We invite and welcome NATO to maintain a leading role in the international military presence and to implement responsibilities that are given on the basis of Resolution 1244 of the Security Council of the United Nations (1999) and the Ahtisaari Plan" (Ibid).

\section{Internationa Administration in Kosovo After the Declaration of Independence}

In October 2008, Serbia had made an official request to the International Court of Justice (ICJ) to give advisory opinion on the legality of the unilateral declaration of Kosovo independence. Fifty countries that had recognized the independence they had submitted in writing their arguments before ICJ. The ICJ advisory opinion, was issued by the court on 22 June 2010, which stated that the unilateral declaration of independence of Kosovo did not violate general principles of international law. International civilian presence to supervise the implementation of the Ahtisaari Plan was made by the International Civilian Office briefly known as ICO. ICO's mandate was to monitor the implementation of the Ahtisaari Plan. In particular, the ICO was interested in the promotion and protection of minority rights in general and in particular the Serb minority. The head of the ICO has had a dual role as head of ICO and representatives of the European Union. ICO's mandate ended in October 2012. (ICO, 2012:1-2).

While, the mission of European Union for law and order was made through the EULEX mission. EULEX mission, apart from monitoring and advisory role in the field of order and security, there has also an executive role for several highprofile cases for which it is intended that Kosovo institutions are still not ready to act. EULEX's mandate was initially set up untill June 2014. Meanwhile, after this time, the EULEX mission has continued with almost the same executive powers for more 'sensitive' cases and advisory for several others. Critics estimate that the EULEX mission has failed to handle high-profile cases. Critical voices were reinforced particularly when the Prosecutor of this mission Mary Bameh publicly accused officials of this mission for corruption and bribery; carried out in cooperation with officials of local institutions. Specifically, the EULEX mission has failed to shed light on the allegations of the Swiss Senator Dick Marty about the trafficking of human organs by the structures of the KLA during the war. 'The judiciary in Kosovo is anathematized after the war by two other powers, from internationals as well as locals. Mandated EULEX has executive powers in sensitive areas such as: Tracking war crimes, Fighting corruption at the highest level and organized crime. Rather than perform the task itself, EULEX has to deal with scandals within the mission for corruption of prosecutors and judges accused from each other for bribery. EULEX has failed completely. The only positive thing is, fear of potential perpetrators to get more attention because they can be pursued by EULEX. The failure of international justice in Kosovo by EULEX and UNMIK even earlier, argues best international demand for creation of the Special Court, which will have the mandate to investigate war crimes. While exactly internationals in Kosovo have also had this responsibility'. (Musliu, B: 2015)

As a result of this failure and other failures in court even though they were initially competence of UNMIK and EULEX then, Kosovo has adopted the necessary constitutional changes to pave the way for the establishment of a Special Court with the mandate to illuminate the allegations for the fate of Serb civilians and other ethnic groups missing during the war in Kosovo.

The Kosovo case shows that non-compliance of the request of the majority citizens of the country and legal basis of the establishment of the international mission, in process creates uncertainty, and as a result the clear vision of where want to achieve. It also helps the creation of tension and suspicion from locals about international administration. As well as the daily work of the decision making international representatives is getting difficult because of the care that must be taken to preserve the spirit of the legal basis on which is set the mission and international balance, as a result of which it is set the mission. This is best shown by the declaration of the SRSG, Bernard Kouchner, who had declared that: "every morning I have to read Resolution 1244, to understand it".(Caplan, 2005:122-123).

Lack of clarity on the status of Kosovo and the lack of consensus on its future, had negative effects during the government of UNMIK 1999-2008. Also after declaring independence, due to the appreciation of the need for continuing 
international presence in Kosovo, through the EULEX mission in the field of security and justice with consulting competence and in some more important even executive, it has come as a result of omissions made during the period of international administration in Kosovo. Due to the lack of expected results and according to the mission that had EULEX has increased dissatisfaction and lost confidence by the citizens of Kosovo. Despite this does not mean that the EULEX mission is utterly failed. Their role especially in consulting and advisory field was and continues to be positive. Because of the desire and determination of the people of Kosovo and other more profiled layers for integration into the European Union and acceptance of the values and the way of functioning of the Western countries, in default way the EULEX is welcome to help in state-building in Kosovo. This is verified by the local people interviewed in the field of security and justice. They despite criticism for their failure, evaluate their help at least for self-confidence and realization of specific missions.

According to the survey conducted with profiled persons and with knowledge about the processes and in particular for EULEX in Kosovo, the answer into six questions was as follows:

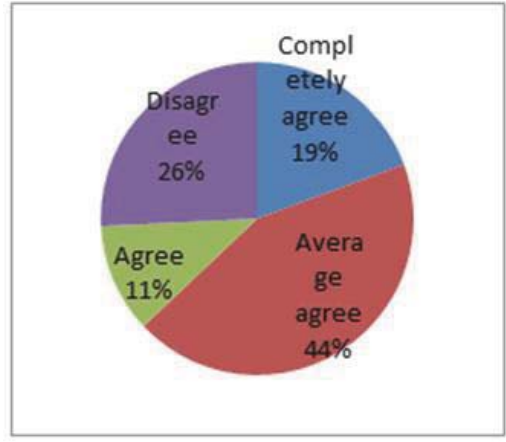

Figure 1.

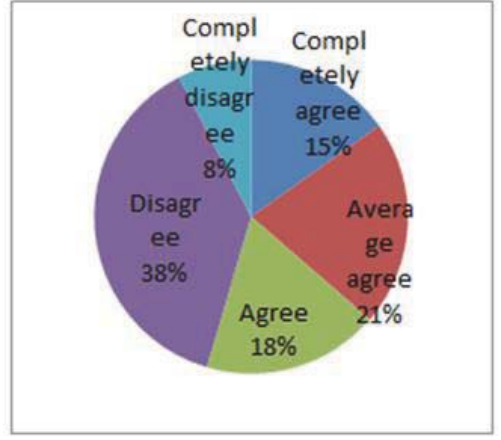

Figure 2.

Source: Data collected by the authors.

Figure I. Of all the institutions in Kosovo, order and security institutions have failed mostly to be consolidated and strengthened after Kosovo's independence.

These data from the figure 1 , best argue that most of our respondents involved in the survey, average agree with the conclusion that the institutions of law and order in Kosovo, compared to all other institutions have mostly failed to consolidate and strengthen. Are exactly the order and security institutions that are managed and administered jointly by locals and internationals after independence until now. While other institutions which are guided only by locals have achieved various successes in the process of state building: some of them are operational and fully functioning, while other institutions still do not have their functions in full capacity.

Figure II: The main reason for this failure refers to the fact that institutions of law and order have split the powers with the EULEX mission (division of sovereignty)?

Whereas from figure 2, However, the majority of respondents did not think the blame for this failure is the fact of sovereignty divided between locals and international in the field of safety and security. So even though the respondents consider that the institutions of law and order have failed most compared to other institutions, and despite the fact that the institutions of order and security have shared powers with internationals, respondents do not think that, the failure refers to the division of competencies or leadership and management together between locals and internationals. 


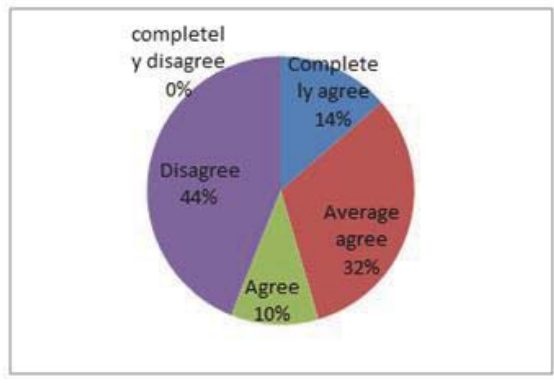

Figure 3

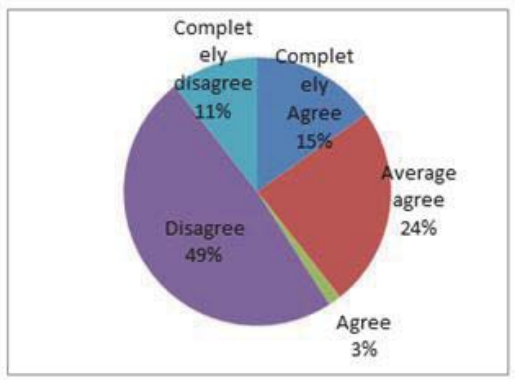

Figure 4

Source: Data collected by the authors.

Figure III. The EULEX mission has failed because officials of the mission did not recognize the land, the environment, and culture of the local population?

The answer in the figure III: The majority of respondents disagree with this statement. However, on average agree 32 percent and 14 percent completely agree, indicating that though in the practice of international administrations, administrators because they did not know the land, the environment and culture of the local population, fail to carry out its mission and objectives. So, management and governance in framework of the international missions in most cases do not have enough time to socialize with the culture and tradition of the people of those territories; international missions deployed quickly and without having the necessary time to plan their activities.

Figure IV: Order and security Institutions in Kosovo would be strengthened more if it would not be the EULEX mission in Kosovo

The answer to the question IV: Despite the majority of respondents agree that the institutions of law and order have failed most notably in comparison with all other institutions, the majority of respondents did not agree with the conclusion that the institutions of law and order in Kosovo will be strengthened more if there was not EULEX mission. So, the respondents still see the role of the EULEX importance in the process of strengthening the institutions of law and order.

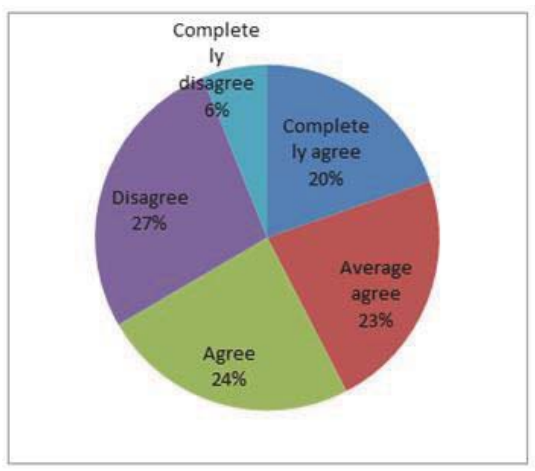

Figure V

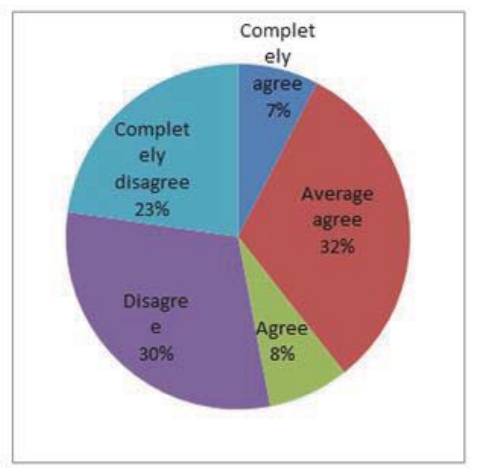

Figure VI

Source: Data collected by the authors.

Figure V: Order and security situation in Kosovo is the same, even worse than before placing EULEX mission for order and security?

Regarding to the question V, It has an undefined opinion and not dominated, with an approximate answer. Despite this, by the analysis of responses for and against, with the deployment of EULEX in Kosovo, the situation has not 
changed dominates 67 percent of the total responses. While disagree the rest. This indicates a negative assessment of the EULEX results.

Figure VI: Do you think that after the departure of EULEX order and security situation in Kosovo will be improved?

From the answers to the question $\mathrm{VI}$, the result is that 53 percent of respondents think that in the period after EULEX would not have improvement of the situation in this field. While the rest of 47 percent think it would improve the situation.

\section{Conclusions}

From what was said above it can be concluded that, Kosovo case has shown that the success or failure of international management depends on the clarity of the establishment, development and termination.

Initially the success of UNMIK mission was great and respectful. As time passed, and the transfer of powers to local institutions, as well as delays in economic development and high unemployment, the dissatisfaction of the citizens of Kosovo increased to UNMIK. This dissatisfaction culminated in the riots of March in 2014. Dissatisfaction consisted of two components:the situation of social and economic difficulties of the citizens and the lack of clear political status. Aa the result of this was created format of the international negotiations, the finalization of which is known as 'conditional independence' (proposal of Martti Ahtisaari). With the declaration of independence of Kosovo in coordination with the international community, but without the support of Russia and China to an extent, resolution 1244, although only formally remains in force. This has resulted even with obstacle in the normal path of Kosovo in terms of recognition.

From research conducted with respondents who are experts onthe field of order and security, despite the fact they accept that the international mission have contributed to the consolidation of institutions in the emergency phase and maintain stability in the country; They have failed to be consolidated and strengthened in comparison with the expectations and needs of Kosovo. UNMIK failed in Kosovo because there was no clear political mandate: was not known which would be the political status of Kosovo after the end of mission. EULEX is very close to capitulation because there has also not a clear mandate, swung between the mandate for the provision of assistance in the field of order and security, and executive powers. When EULEX failed the fault remain to the locals; the successes attribute to themselves. Similarly, when the judiciary fails in Kosovo fault remained to EULEX; the successes atributte to themselves. So there is no clear placement, development, and termination. It remains to be seen what will happen with the Special Court; although viewed chronologically, the tradition of international missions in Kosovo leaves little to be desired.

\section{References}

ATSH, 2014: Letter of Jahjaga to Ashton: I will ask for extension of EULEX mission and establishing of Kosovo Court. Source: http://www.ata.gov.al/leter-ashton-jahjaga-do-kerkoj-vazhdimin-e-misionit-te-eulex-it-dhe-themelimin-e-gjykates-se-kosoves91553.html Accessed 23.05.2015

Caplan, R. (2005a) Europe and the Recognition of New States in Yugoslavia. Cambridge, Cambridge University Press.

Caplan, R.(2005b). International Governance of War-Torn Territories, Rule and Reconstruction. Oxfrod Universitypress. New York.

Chesterman, S.(2005) You the People, The United Nations, Transitional Administration, and State-Building. Oxfrod Universitypress. New York.

ICO. (2012):State Building and Exit The International Civilian Office and Kosovo's Supervised Independence 2008 - 2012. Prishtina, Kosovo. Electronic source: https://dgap.org/sites/default/files/article_downloads/state_building_and_exit_-_reducedfile. pdf Accessed: 23.05 .2015

Knudsen, B.T dheLausten, B.C (2006) Kosovo between War and Peace: Nationalism, peacebuilding and International trusteeship.New York, Taylor \& Francis e-library.

Kosovo Declaration of Independence :http://www.kuvendikosoves.org/common/docs/Dek_Pav_e.pdf

Kosovo Constitution: http://www.kuvendikosoves.org/?cid=2,100,48

Lindsey, K.J(2009). Kosovo The Path to Contested Statehood in the Balkans, London: I.B.Tauris \& Co Ltd.

Musliu, B(2015): "Betimi për Drejtësi",Forum organized by Friedrich Naumann

Stiftung/ Liberal Institute for Policy Research, Prishtinë, 29.05.2015.

Pellet, A.(1992). "The Opinions of the Badinter Arbitration Committee: A Second Breath for the Self-Determination of Peoples". European Journal of International Law. Source: http://ejil.org/pdfs/3/1/1175.pdf

Reports of the General Secretary of the UN (S2008/692): http://www.un.org/en/ga/search/view_doc.asp?symbol=S/2008/692; (S2208/354): http://www.un.org/en/ga/search/view_doc.asp?symbol=S/2008/354; (S2209/300): http://www.un.org/en/ga/search/ view_doc.asp?symbol=S/2009/300

Rüdiger, Wolfrum(2005). International Administration in Post-Conflict Situations by the United Nations and Other International Actors. Koninklijke Brill N.V. Printed in The Netherlands 
Simonse.G.S(2004) Nationbuilding as Peacebuilding:Racing to Define the Kosovar. International Peace Research Institute, Oslo. International Peacekeeping, Vol.0, No.0, Summer 2004, pp.289-311

ISSN 1353-3312/1743-906X onlineDOI:10.1080/1353331042000237283 \# 2004 Taylor \&Francis Ltd.

Tansey, O.(2009) Regime-Building: Democratization and International Administration, Oxford: Oxford University Press.

Visoka, G.(2013) UNMIK after Kosovo Independence: Exit Strategy or 'Exist' Strategy? Kosovo Institute of Peace. Source: https://www.academia.edu/7598370/UNMIK_After_Kosovo_Independence_Exit_or_Exist_Strategy Accessed: 21.02.2015. 